\author{
A. Entomology \\ ISSN: $1687-8809$ \\ www.eajbs.eg.net
}

\title{
Seasonal activity of the red-striped soft scale insect, Pulvinaria tenuivalvata (Hemiptera:Coccidae) infesting sugarcane fields at Qena, Egypt
}

\author{
Bakry, M. M. S.; Mahmoud, G. H.; Abd-Rabou, S. and El-Amir, S. M. \\ Plant Protection Research Institute, Agricultural Research Center, Dokki, Giza, Egypt.
}

\section{ABSTRACT}

The red-striped soft scale insect, Pulvinaria tenuivalvata (Newstead) (Hemiptera : Coccidae) is a serious pest on sugarcane. As a basic study for developing future management of this scale species, seasonal activity of different stages of this insect was carried out through two successive seasons (2006/2007 and 2007/2008) at Esna district, Qena governorate. The obtained results showed that, P. tenuivalvata had four peaks occurred in mid of July, mid-September, beginning of November and beginning of December per season. The second season of study cleared that the total population of this insect was higher in comparison to the first season of investigation, which may due to the influence of favourable factors. The combined effect of the tested weather factors was responsible about some in the total population. The percentages of explained variance (E.V.) indicate that all tested variables were together responsible for (30.6 and $42 \%$ ) during the two seasons of study, respectively.

Keywords: Seasonal activity, Pulvinaria tenuivalvata, sugarcane fields, Qena, Egypt

\section{INTRODUCTION}

Sugarcane, Saccharum officinarum (Family: Poaceae) is an economic important field crop and the main source of sugar production in Egypt, in addition to produce black honey, fresh juice and several chemical sub-products. It cultivate with large scale in Upper Egypt, especially in Qena governorate (it cultivated about 50\% of total sugarcane in Egypt). In the last few years, the cultivated areas were attacked greatly with the sugarcane soft scale insect, Pulvinaria tenuivalvata (Newstead) (Hemiptera : Coccidae). The pest suck the cell sap of the leaves and excrete a large amount of honeydew that cover plant leaves and attract ants on leaves and encourages the growth of sooty mould fungus which give the infested dirty black appearance that affect on photosynthesis and respiration processes of sugarcane plants (Ali et al., 2000). Under severe attack, the pest causes economic loss in both sugarcane quality and quantity (Besheit et al., 2002). Many authors reported the soft scale insect, $P$. tenuivalvata as a serious pest attacking sugarcane plantations (Ali et al., 2000, Shalaby, 2002 and Tohamy et al., 2002).

The objective of this study is to estimate the seasonal activity, stage structure, rate of monthly variation and effect of temperature and relative humidity on the population of this insect was carried out for two successive seasons in sugarcane field at Esna district, Qena Governorate.

\section{MATERIALS AND METHODS}

The present work was carried out in sugarcane fields heavily infested by $P$. tenuivalvata at Esna district, Qena Governorate in an area about one feddan. The

Workshop of Scale Insects and their role in agricultural development in Egypt. Held in Agricultural Research Center, Plant Protection Research Institute, Scale Insects Division (2012) 
experimental was planted on 15/3/2006 (spring plantation) was arranged in Randomized Complete Block Design contain four replicates. The selected sugarcane field was cultivated with G.T. 54/9 variety and receives all the recommended agricultural practices, homogeneous in plant growth and without application any chemical control measures before and during the period of investigation.

The samples was selected randomly with rate of 25 leaves/replicate Regular half-monthly samples of 100 leaves from four replicates after 75 days from planting. The collected samples were transferred to the laboratory in polyethylene bags for inspection by the aid of stereomicroscope binocular. The stages of this insect on upper and lower surfaces of the sugarcane leaves individually sorted into live nymph and adult females then counted and recorded. equation:

The relative abundance (A) was calculated according to the following

$$
A=(n / N) X 100 .
$$

Where, $\mathrm{A}=$ The relative abundance.

$\mathrm{n}=$ Number of populations in which the pest appeared.

$\mathrm{N}=$ Total number of populations taken allover the season.

Also, the rate of monthly variation (R.M.V.P) in population density was calculated according to (Serag-El-Dien, 1998).

\section{Means count given at a month}

\section{$($ R.M.V.P) $=\overline{\text { Means count in the preceding month }}$}

The weather factors namely the maximum temperature, minimum temperature and mean \% relative humidity (R.H.) was obtained from the Central Laboratory for Agriculture Meteorology, Agriculture Research Center, Ministry of Agriculture in Giza. The effect of tested weather factors on this insect activity was adopted by using the simple correlation, regression coefficient and the partial regression (Fisher, 1950). All of these statistical analyses in this present work were carried out by computer (MSTATC Program) to determine the preferable time for the insect activity and the proper time for its control.

\section{RESULTS AND DISCUSSION}

\section{A- Seasonal activity of $P$. tenuivalvata:}

In the first season of study (2006/2007) as shown in Fig. (1), it was observed that, the total population of this insect started to increase gradually to reaching the first peak of 306.9 individuals $/ 25$ leaves in the mid of July at $42.7^{\circ} \mathrm{C}$ (Max. temp), $23.9^{\circ} \mathrm{C}$ (Min. temp) and $28.6 \%$ R.H. Then, the population decreased in beginningAugust and thereafter it increased continuously towards the second peak of 511.9 that was recorded in mid- September when the individuals reached 511.9 at $40.4^{\circ} \mathrm{C}$ (Max. temp), $15.8^{\circ} \mathrm{C}$ (Min. temp) and $19.8 \%$ R.H. another decrease in population took place in the next month till mid-October and then it increased making the third peak in the beginning of November, when 352.3 individuals were recorded at field conditions of $34.8^{\circ} \mathrm{C}$ (Max. temp), $7.8^{\circ} \mathrm{C}$ (Min. temp) and 39.6\% R.H. The fourth peaks of 356.5 individuals $/ 25$ leaves were occurred in beginning-December at $27.8^{\circ} \mathrm{C}$ (Max. temp), $3.1^{\circ} \mathrm{C}$ (Min. temp) and 39.6\% R.H. (Fig. 1). These results are almost in agreement with those of Ali et al. (2000) in Egypt, reported that this scale insect was active from May to December and the maximum population was observed through OctoberNovember. EI-Serwy (2001) found that the percentage of sugarcane infestation by the 
P. tenuivalvata reached $100 \%$ in mid of November and the population reached the maximum size during the end of September, and mid of December.
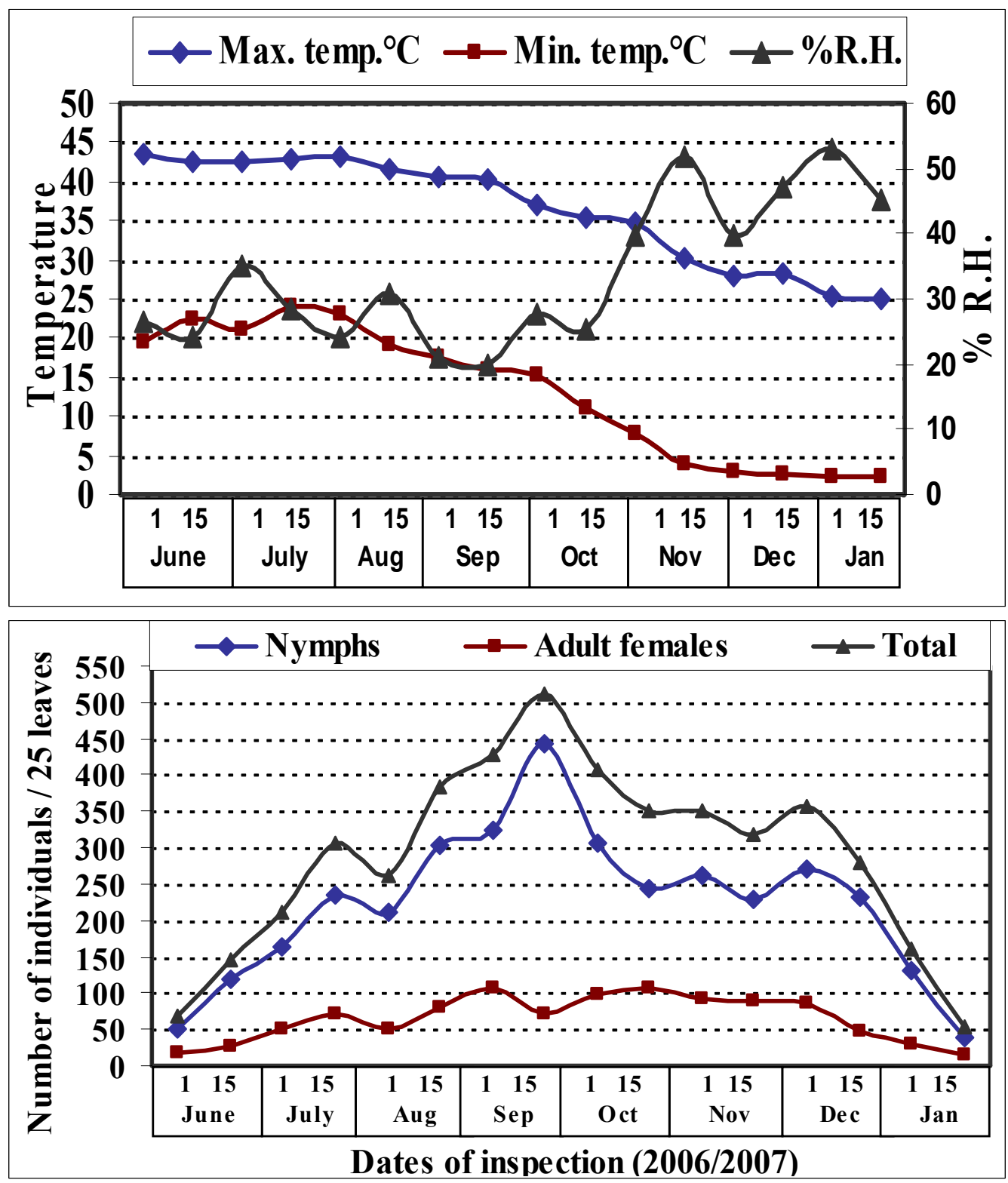

Fig. 1: Numbers of Pulvinaria tenuivalvata counted on sugarcane leaves at 15 day intervals during the 2006/2007 season, with corresponding records of climatic factors at Esna district, Qena Governorate, Egypt.

Relative to the overall seasonal counts in Table (1), it was evident that the highest percentages of nymphs, and total population $(21.5 \%$, and $20.5 \%$ of the grand total, respectively) were recorded in September. While, adult females $(19.9 \%)$ were took place in October. In contrary, the lowest percentages of the overall seasonal counts were $(4.7 \%)$ both of nymphs and total population were obtained in January 2007, while adult females (4.3\%) were took place in June (Table, 2).

Concerning, the data during the second season of study (2007/2008) as shown in Fig. (2) and Table (3), it was cleared that the total population was higher in comparison to the first season of investigation. In the same table, the least population density of $P$. tenuivalvata nymphs (67.6 individuals) and total population (87.4 individuals/25 leaves) were recorded in the beginning of June 2007. While, the adult females (15.6 individuals/25 leaves) were found in mid-January 2008. 
Table 1: Population density of Pulvinaria tenuivalvata counted on 25 sugarcane leaves, with the records of climatic factors at Esna district, Qena Governorate during the period from June, 2006 to January, 2007.

\begin{tabular}{|c|c|c|c|c|c|c|c|}
\hline \multirow{2}{*}{\multicolumn{2}{|c|}{ Inspected date }} & \multicolumn{3}{|c|}{ No. / 25 leaves } & \multicolumn{3}{|c|}{ Climatic factors } \\
\hline & & \multirow{2}{*}{$\begin{array}{c}\text { Nymphs } \\
51.5 \\
\end{array}$} & \multirow{2}{*}{$\begin{array}{c}\text { Adult females } \\
17.5 \\
\end{array}$} & \multirow{2}{*}{$\begin{array}{c}\text { Total } \\
69.0 \\
\end{array}$} & \multirow{2}{*}{$\frac{\text { Max. temp. }}{{ }^{\circ} \mathbf{C}}$} & \multirow{2}{*}{$\frac{\text { Min. temp. }{ }^{\circ} \mathbf{C}}{19.6}$} & \multirow{2}{*}{$\begin{array}{c}\text { \%R.H. } \\
26.4 \\
\end{array}$} \\
\hline June 2006 & 1 & & & & & & \\
\hline & 15 & 119.1 & 27.5 & 146.6 & 42.6 & 22.4 & 24.2 \\
\hline \multirow{2}{*}{ July } & 1 & 162.6 & 49.9 & 212.5 & 42.5 & 21.0 & 35.2 \\
\hline & 15 & 235.3 & 71.5 & 306.9 & 42.7 & 23.9 & 28.6 \\
\hline \multirow{2}{*}{ August } & 1 & 212.1 & 50.6 & 262.8 & 43.3 & 23.2 & 24.2 \\
\hline & 15 & 302.0 & 80.2 & 382.1 & 41.44 & 19.3 & 30.8 \\
\hline \multirow{2}{*}{ Sept. } & 1 & 323.6 & 105.5 & 429.2 & 40.7 & 17.6 & 20.9 \\
\hline & 15 & 442.0 & 69.9 & 511.9 & 40.4 & 15.8 & 19.8 \\
\hline \multirow{2}{*}{ Oct. } & 1 & 306.9 & 99.3 & 406.1 & 37.1 & 15.3 & 27.5 \\
\hline & 15 & 244.4 & 107.6 & 352.1 & 35.4 & 11.0 & 25.3 \\
\hline \multirow{2}{*}{ Nov. } & 1 & 260.5 & 91.8 & 352.3 & 34.8 & 7.8 & 39.6 \\
\hline & 15 & 229.5 & 88.8 & 318.3 & 30.3 & 3.7 & 51.7 \\
\hline \multirow{2}{*}{ Dec. } & 1 & 270.3 & 86.2 & 356.5 & 27.8 & 3.1 & 39.6 \\
\hline & 15 & 231.1 & 48.9 & 280.1 & 28.2 & 2.8 & 47.3 \\
\hline \multirow{2}{*}{ Jan. 2007} & 1 & 130.5 & 31.0 & 161.5 & 25.4 & 2.4 & 52.8 \\
\hline & 15 & 38.4 & 15.1 & 53.6 & 25.1 & 2.3 & 45.1 \\
\hline \multicolumn{2}{|c|}{ Total } & 3559.9 & 1041.4 & 4601.2 & & & \\
\hline
\end{tabular}

Table (2): Sums, averages and the percentages from the overall seasonal grand total of Pulvinaria tenuivalvata (Newstead) counted on sugarcane leaves at Esna district, Qena Governorate from June, 2006 to January, 2007.

\begin{tabular}{|c|c|c|c|c|c|c|c|c|c|c|}
\hline \multirow{2}{*}{\multicolumn{2}{|c|}{ Inspected date }} & \multicolumn{3}{|l|}{ Nymphs } & \multicolumn{3}{|c|}{ Adult females } & \multicolumn{3}{|l|}{ Total } \\
\hline & & \multirow{2}{*}{$\begin{array}{c}\text { Sum } \\
170.6 \\
\end{array}$} & \multirow{2}{*}{$\begin{array}{c}\text { Aver. } \\
85.3 \\
\end{array}$} & \multirow{2}{*}{$\begin{array}{c}\begin{array}{c}\% \text { from } \\
\text { overall } \\
\text { seasonal } \\
\text { total }\end{array} \\
4.8 \\
\end{array}$} & \multirow{2}{*}{$\begin{array}{l}\text { Sum } \\
45.0 \\
\end{array}$} & \multirow{2}{*}{$\begin{array}{l}\text { Aver. } \\
22.5 \\
\end{array}$} & \multirow{2}{*}{$\begin{array}{c}\begin{array}{c}\% \text { from } \\
\text { overall } \\
\text { seasonal } \\
\text { total }\end{array} \\
4.3 \\
\end{array}$} & \multirow{2}{*}{$\begin{array}{l}\text { Sum } \\
215.5 \\
\end{array}$} & \multirow{2}{*}{$\begin{array}{c}\text { Aver. } \\
107.8 \\
\end{array}$} & \multirow{2}{*}{$\begin{array}{c}\begin{array}{c}\% \text { from } \\
\text { overall } \\
\text { seasonal } \\
\text { total }\end{array} \\
4.71 \\
\end{array}$} \\
\hline \multirow{7}{*}{ 离 } & June & & & & & & & & & \\
\hline & July & 398.0 & 199.0 & 11.2 & 121.4 & 60.7 & 11.7 & 519.4 & 259.7 & 11.3 \\
\hline & Oct. & 551.3 & 275.6 & 15.5 & 206.9 & 103.5 & 19.9 & 758.2 & 379.1 & 16.5 \\
\hline & Nov. & 490.0 & 245.0 & 13.8 & 180.6 & 90.3 & 17.3 & 670.6 & 335.3 & 14.6 \\
\hline & Dec. & 501.4 & 250.7 & 14.1 & 135.1 & 67.6 & 13.0 & 636.6 & 318.3 & 13.8 \\
\hline & Jan. & 168.9 & 84.5 & 4.7 & 46.1 & 23.1 & 4.4 & 215.0 & 107.5 & 4.7 \\
\hline & Total & 3559.8 & & 100.0 & 1041.3 & & 100.0 & 4601.2 & & 100.0 \\
\hline
\end{tabular}

Table 3:Population density of Pulvinaria tenuivalvata counted on 25 sugarcane leaves, with the records of climatic factors at Esna district, Qena Governorate during the period from June, 2007 to January, 2008.

\begin{tabular}{|c|c|c|c|c|c|c|c|}
\hline \multirow{2}{*}{\multicolumn{2}{|c|}{ Inspected date }} & \multicolumn{3}{|c|}{ No. / 25 leaves } & \multicolumn{3}{|c|}{ Climatic factors } \\
\hline & & \multirow{2}{*}{$\begin{array}{c}\text { Nymphs } \\
67.6\end{array}$} & \multirow{2}{*}{$\begin{array}{c}\text { Adult females } \\
19.8\end{array}$} & \multirow{2}{*}{$\begin{array}{c}\text { Total } \\
87.4\end{array}$} & \multirow{2}{*}{$\frac{\text { Max. temp. }{ }^{\circ} \mathbf{C}}{42}$} & \multirow{2}{*}{$\begin{array}{c}\text { Min. temp. }{ }^{\circ} \mathbf{C} \\
18.7\end{array}$} & \multirow{2}{*}{$\begin{array}{r}\text { \%R.H. } \\
53.9\end{array}$} \\
\hline June 2007 & 1 & & & & & & \\
\hline & 15 & 93.9 & 26.6 & 120.5 & 43 & 21.7 & 52.8 \\
\hline \multirow{2}{*}{ July } & 1 & 134.7 & 49.2 & 183.8 & 42.9 & 22.4 & 28.6 \\
\hline & 15 & 181.7 & 85.7 & 267.5 & 42.5 & 25.3 & 23.1 \\
\hline \multirow{2}{*}{ August } & 1 & 164.9 & 71.5 & 236.4 & 41.3 & 22.6 & 31.9 \\
\hline & 15 & 245.6 & 115.8 & 361.4 & 39 & 19.6 & 39.6 \\
\hline \multirow{2}{*}{ Sept. } & 1 & 304.5 & 130.5 & 435.01 & 39.2 & 17.9 & 36.3 \\
\hline & 15 & 323.9 & 119.5 & 443.4 & 48.3 & 18.8 & 30.8 \\
\hline \multirow{2}{*}{ Oct. } & 1 & 312.2 & 107.2 & 419.4 & 48.3 & 17.5 & 39.6 \\
\hline & 15 & 279.6 & 105.1 & 384.7 & 39.8 & 18.9 & 36.3 \\
\hline \multirow{2}{*}{ Nov. } & 1 & 300.3 & 95.8 & 396.1 & 36.9 & 12.7 & 48.4 \\
\hline & 15 & 254.7 & 64.5 & 319.2 & 34.7 & 10 & 40.7 \\
\hline \multirow{2}{*}{ Dec. } & 1 & 289.4 & 73.2 & 362.6 & 32.3 & 5.9 & 51.7 \\
\hline & 15 & 258.1 & 50.6 & 308.6 & 27.8 & 3.1 & 42.9 \\
\hline \multirow{2}{*}{ Jan. 2008} & 1 & 244.6 & 59.5 & 304.1 & 27 & 2.2 & 41.8 \\
\hline & 15 & 209.1 & 15.6 & 224.8 & 20.8 & 1.7 & 53.9 \\
\hline \multicolumn{2}{|l|}{ Total } & 3664.8 & 1190 & 4854.8 & & & \\
\hline
\end{tabular}



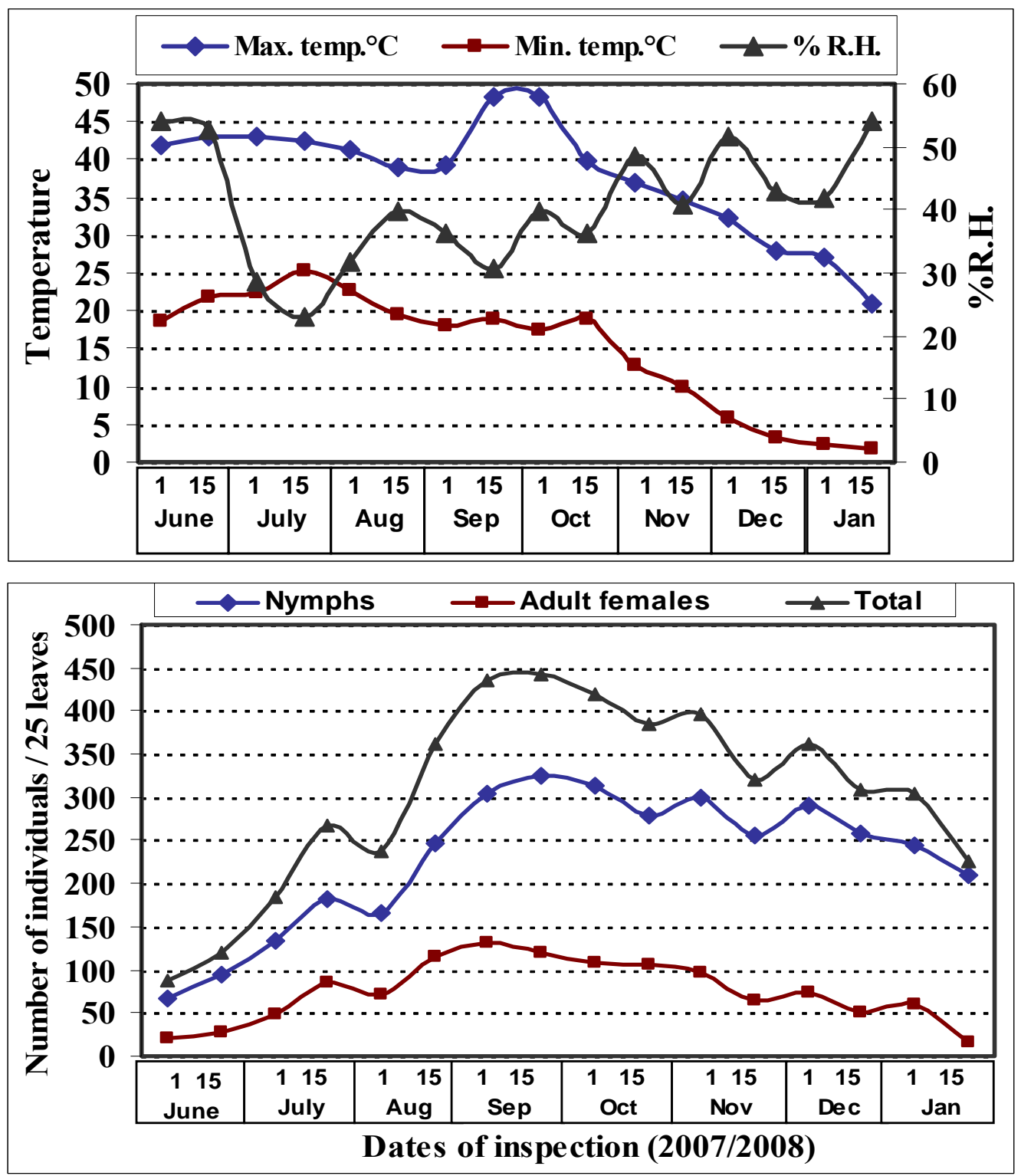

Fig. 2: Numbers of Pulvinaria tenuivalvata counted on sugarcane leaves at 15-day intervals during the 2007/2008 season, with corresponding records of climatic factors at Esna district, Qena Governorate, Egypt.

The highest percentage of the overall season count of nymphs (17.1\%), adult females $(20.9 \%)$ and total population $(18.08 \%)$ were recorded in September. Moreover, the lowest percentage of nymphs $(4.4 \%)$, adult females $(3.9 \%)$ and total population (4.28\%) took place in June 2007 in Table (4). Base on the data obtained during the two successive seasons of study, it could be concluded that the total population of this insect had four peaks, which was recorded in the mid-July, midSeptember, beginning of November and beginning of December. These data were confirmed by the findings of EI-Serwy (2001), Tohamy et al. (2002) and Ahmed (2004) in Egypt they reported that the red-striped soft scale insect, $P$. tenuivalvata had four generations per season.

In summer months, it is obvious that, the insect population was higher and thus due to the environmental conditions which were more suitable for the insect activity.

\section{B. Stage structure population:}

The study of the dynamics of natural biological population is often hampered by the difficulty of determining the ages of individuals. However, this problem can 
sometimes be circumvented by working in terms of a stage structure rather an age structure (Manly, 1990). According to the data obtained in Tables (1-3), the stage structure of this insect on sugarcane showed a total population of 4601.2 and 4854.8 individuals in 2006-2007 and 2007-2008, respectively. Preadults were represented by 3559.8 and 3664.8 individuals $(77.37 \%$ and $75.49 \%$ of the total population) in 20062007 and 2007-2008, respectively. While, the adult females were represented by 1041.4 and 1190 individuals ( $22.63 \%$ and $24.51 \%$ of the total population) during the two growing seasons of the study, respectively.

Table 4: Sum, average and the percentage from the overall seasonal grand total of Pulvinaria tenuivalvata (Newstead) counted on sugarcane leaves at Esna district, Qena Governorate from June, 2007 to January, 2008.

\begin{tabular}{|c|c|c|c|c|c|c|c|c|c|c|}
\hline \multirow{2}{*}{\multicolumn{2}{|c|}{ Inspected date }} & \multicolumn{3}{|c|}{ Nymphs } & \multicolumn{3}{|c|}{ Adult females } & \multicolumn{3}{|c|}{ Total } \\
\hline & & \multirow{2}{*}{$\begin{array}{c}\text { Sum } \\
161.5\end{array}$} & \multirow{2}{*}{$\begin{array}{c}\text { Aver. } \\
80.7\end{array}$} & \multirow{2}{*}{$\begin{array}{c}\begin{array}{c}\text { \%from } \\
\text { overall } \\
\text { seasonal } \\
\text { total }\end{array} \\
4.4\end{array}$} & \multirow{2}{*}{$\begin{array}{l}\text { Sum } \\
46.4\end{array}$} & \multirow{2}{*}{$\begin{array}{c}\text { Aver. } \\
23.2\end{array}$} & \multirow{2}{*}{$\begin{array}{c}\begin{array}{c}\% \text { from } \\
\text { overall } \\
\text { seasonal } \\
\text { total }\end{array} \\
3.9\end{array}$} & \multirow{2}{*}{$\begin{array}{c}\text { Sum } \\
207.8\end{array}$} & \multirow{2}{*}{$\begin{array}{c}\text { Aver. } \\
103.9\end{array}$} & \multirow{2}{*}{$\begin{array}{c}\begin{array}{c}\% \text { from } \\
\text { overall } \\
\text { seasonal } \\
\text { total }\end{array} \\
4.3 \\
\end{array}$} \\
\hline \multirow{9}{*}{ 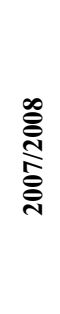 } & June & & & & & & & & & \\
\hline & July & 316.4 & 158.2 & 8.6 & 134.9 & 67.5 & 11.3 & 451.3 & 225.7 & 9.3 \\
\hline & Aug. & 410.5 & 205.2 & 11.2 & 187.3 & 93.7 & 15.7 & $\begin{array}{l}597.8 \\
\end{array}$ & 298.9 & 12.3 \\
\hline & Sept. & 628.4 & 314.2 & 17.1 & 250.0 & 125.0 & 20.9 & $\begin{array}{l}878.4 \\
\end{array}$ & 439.2 & 18.1 \\
\hline & Oct. & 591.8 & 295.9 & 16.1 & 212.3 & 106.1 & 17.8 & 804.1 & 402.0 & 16.5 \\
\hline & Nov. & 555.0 & 277.5 & 15.1 & 160.3 & 80.2 & 13.4 & 715.3 & 357.7 & 14.7 \\
\hline & Dec. & 547.5 & 273.8 & 14.9 & 123.7 & 61.9 & 10.4 & 671.2 & 335.6 & 13.8 \\
\hline & Jan. & 453.7 & 226.8 & 12.4 & 75.2 & 37.6 & 6.3 & 528.8 & 264.4 & 10.9 \\
\hline & Total & 3664.8 & & 100 & 1190.0 & & 100 & 4854.8 & & 100 \\
\hline
\end{tabular}

\section{Rate of monthly variation of the red-striped soft scale insect, $P$. tenuivalvata population:}

Monthly variation rate of the population density of Nymphs, adult females and the total population were calculated according to the formula described by Serag-ElDien (1998).As regarding to the favourable time of annual increase for nymphs, it appeared to be during July, August, September and December during the two seasons (2006-2007 and 2007-2008), however, the rates of monthly variation was 2.33, 1.29, 1.49 and 1.02 during the first season, respectively, but it was 1.96, 1.3 and 1.53 during the second season in July, August and September, respectively (Table, 3). Similarly, the rates of monthly variation for adult females showed that the favourable times for annual increase seemed to be from July, August, September and October during the $1^{\text {st }}$ season when the rate of monthly variation was $2.7,1.08,1.34$ and 1.18 , respectively, however, the second season it was 2.91, 1.39 and 1.33 during in July, August and September respectively.

Concerning the rates of monthly variation (R.M.V.P) for total population, it appeared that the favourable times for annual increase was also during the period from July, August and September during the two seasons. The rates of monthly variation were $2.41,1.24$ and 1.46 in the first season. While, in the second season were 2.17, 1.32 and 1.47 (Table 5).

For all stages, the favourable times of the annual increase were during the period from July, August and September (Table, 3). Dent (1991) stated that the seasonal phenology of insect numbers, the number of generations, and the level of insect abundance at any location are influenced by the environmental factors at that location. Ahmed (2004) stated that summer months are the favorable for the population growth and activity of $P$. tenuivalvata. 
Table 5: Rate of monthly variation (R.M.V.P) in the mean number of Pulvinaria tenuivalvata counted on sugarcane leaves at Esna district, Qena Governorate through the two successive seasons (2006-2008).

\begin{tabular}{|c|c|c|c|c|}
\hline \multirow{2}{*}{ Season } & \multirow{2}{*}{ Inspected month } & \multicolumn{3}{|c|}{ Rate of monthly variation } \\
\hline & & Nymphs & Adult females & Total \\
\hline \multirow{8}{*}{ 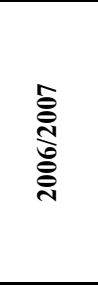 } & June & - & - & - \\
\hline & July & 2.33 & 2.70 & 2.41 \\
\hline & August & 1.29 & 1.08 & 1.24 \\
\hline & September & 1.49 & 1.34 & 1.46 \\
\hline & October & 0.72 & 1.18 & 0.81 \\
\hline & November & 0.89 & 0.87 & 0.88 \\
\hline & December & 1.02 & 0.75 & 0.95 \\
\hline & January & 0.34 & 0.34 & 0.34 \\
\hline \multirow{8}{*}{ 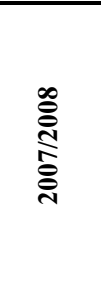 } & June & - & - & - \\
\hline & July & 1.96 & 2.91 & 2.17 \\
\hline & August & 1.30 & 1.39 & 1.32 \\
\hline & September & 1.53 & 1.33 & 1.47 \\
\hline & October & 0.94 & 0.85 & 0.92 \\
\hline & November & 0.94 & 0.76 & 0.89 \\
\hline & December & 0.99 & 0.77 & 0.94 \\
\hline & January & 0.83 & 0.61 & 0.79 \\
\hline
\end{tabular}

\section{Effect of main climatic weather factors on the total population density of $\boldsymbol{P}$. tenuivalvata:}

\section{A. Effect of maximum temperature:}

The results in Table (6), it showed that the correlation coefficient (r) between maximum temperature and total population was positive insignificant relation $(+0.17$ and +0.14 ), in the both seasons, respectively. As well as, the unit effect (regression coefficient) indicates that an increased of $1{ }^{\circ} \mathrm{C}$ in the maximum temperature increase the population (3.19 and 1.2 individuals per 25 leaves) for the $1^{\text {st }}$ and $2^{\text {nd }}$ season, respectively. Also, the partial regression values emphasized a positive and insignificant relation $(+21.7$ and +13.4$)$ in the two seasons of study.

Table (6): Effect of both temperature and relative humidity on the population density of Pulvinaria tenuivalvata on 25 sugarcane leaves at Esna district, Qena Governorate through the two successive seasons of investigation (2006-2008).

\begin{tabular}{|c|c|c|c|c|c|c|c|c|}
\hline \multirow{2}{*}{$\begin{array}{l}\tilde{0} \\
\tilde{0} \\
\tilde{D}\end{array}$} & \multirow[t]{2}{*}{ Weather factors } & \multicolumn{2}{|c|}{$\begin{array}{l}\text { Simple correlation and } \\
\text { regression values }\end{array}$} & \multirow{2}{*}{$\begin{array}{c}\begin{array}{c}\text { Partial regression } \\
\text { values }\end{array} \\
\text { P.reg }\end{array}$} & \multicolumn{4}{|c|}{ Analysis variance } \\
\hline & & $\mathrm{R}$ & B & & $F$ values & MR & $\mathrm{R}^{2}$ & E.V\% \\
\hline \multirow{3}{*}{ ¿्ं } & Max. temp & 0.169 & 3.194 & 21.7 & \multirow{3}{*}{1.76} & \multirow{3}{*}{0.553} & \multirow{3}{*}{0.306} & \multirow{3}{*}{30.6} \\
\hline & Min. temp & 0.075 & 1.174 & -24.7 & & & & \\
\hline & \%R.H. & -0.344 & -4.066 & -7.93 & & & & \\
\hline \multirow{3}{*}{ ¿̊유 } & Max. temp & 0.084 & 1.196 & 13.4 & \multirow{3}{*}{2.94} & \multirow{3}{*}{0.648} & \multirow{3}{*}{0.420} & \multirow{3}{*}{42.0} \\
\hline & Min. temp & -0.143 & -1.98 & $-17.5^{*}$ & & & & \\
\hline & \%R.H. & -0.293 & -3.38 & -6.25 & & & & \\
\hline
\end{tabular}

$\mathrm{r}=$ Simple correlation

$\mathrm{b}=$ Simple regression

P.reg $=$ Partial regression
$\mathrm{MR}=$ Multiple correlation

$\mathrm{R}^{2}=$ Coefficient of determination

E.V\% $\%$ Explained variance

\section{B- Effect of minimum temperature:}

Concerning the first season of study, the results of simple coefficient (r), showed a positive insignificant correlation between the minimum temperature and the insect population ( $\mathrm{r}$ values were +0.075 ) for the first season. While, it was negatively insignificant correlation ( $\mathrm{r}$ value occurred -0.143 ) for the second season. As well as, 
the unit effect (regression coefficient) indicates that an increased of $1{ }^{\circ} \mathrm{C}$ in the minimum temperature increased the population (1.17 individuals per 25 leaves) for the first season. But, decreased (1.98 individuals per 25 leaves), for the second season. The precise effect of the minimum temperature on the insect population showed that it was negative insignificant effect (P.reg values was -24.7) in the first season, while negative significant (-17.5) in the second season (Table 6).

\section{Effect of relative humidity:}

The effect of relative humidity on the insect activity during the first season had insignificant negative effect (the correlation coefficient (r) was -0.34 and -0.29 ) for $1^{\text {st }}$ and $2^{\text {nd }}$ seasons, respectively (Table, 6). Also, the calculated regression coefficient (b) for the effect this factor indicated that for every $1 \%$ R.H. increased in the relative humidity, the population density decreased by 4.1 and 3.4 individuals per 25 leaves in the two seasons. To determine the real effect of the relative humidity, partial regression was carried out. The obtained results showed that this factor was insignificant negative effect (P.reg value was -7.93 and -6.25) for the first and second seasons, respectively. These results may reflect the feeble role played by each of the tested variable separately, on the rate of $P$. tenuivalvata population increase or decrease in the sugarcane plantations.

\section{The combined effects of the three factors (maximum temperature, minimum temperature and percentage relative humidity) on the total population activity:}

The estimated partial regression values indicated the presence of a simultaneous effect of these factors on the population of insect in both years. The obtained results revealed that the combined effect of these tested weather factors (Table 6) was insignificant where the calculated " $F$ " values were (1.76 and 2.94) throughout the two seasons of study, respectively. The influence of these combined climatic factors was expressed in Table (6) as percentages of explained variance (E.V.) for $1^{\text {st }}$ and $2^{\text {nd }}$ seasons, it being $(30.6$ and $42 \%)$ during the two seasons of study respectively. The remaining unexplained variances are assumed to be due to the influences of other unconsidered factors (Environmental,... etc.) in addition, of course, to the experimental error. The previous results indicated that the activity of this insect was mostly related to the simultaneous effect of these selected weather factors rather than the single effect of each factor separately of $P$. tenuivalvata. These results agreed with that obtained by (EI-Serwy, 2001 and Ahmed, 2004).

\section{REFERENCES}

Ahmed, A. O. A. (2004): Studies on the red-striped soft scale insect, Pulvinaria tenuivalvata (Newstead), infesting sugarcane in Upper Egypt. M.Sc. Thesis, Fac. Agric., Assiut Univ., 142 pp.

Ali, M. A. M.; EI-Kholy, A. J.; El-Metwally, E. M. F. and Shalaby, M. I. (2000): Occurrence, distribution and host range of the sugarcane soft scale insect, Pulvinaria tenuivalvata (Newstead) in Upper Egypt. Bull. Ent. Soc. Egypt, 78: 243-250.

Besheit, S. Y.; Abaziad, A. A.; Gomaa, A. M. E. S. and El-Hamd, A. S. A. (2002): The influence of the infestation by the soft scale insect, Pulvinaria tenuivalvata (Newstead) (Homoptera: Coccidea) on sugarcane stalk weight, juice quality and sugar yield in Upper Egypt. Assuit J. Agric. Sci., 33(4): 1728.

Dent, D. (1991): Insect Pest Management. C.A.B. International. 
EI-Serwy, S. A. (2001): Ecology, biology and natural enemies of the red-striped soft scale insect, Pulvinaria tenuivalvata (Newstead) (Homoptera: Coccidea), a pest of sugarcane in Egypt. Bull. Ent. Soc. Egypt, 79: 13-35.

Fisher, R. A. (1950): Statistical methods for research workers. Oliver and Boyd Ltd., Edinburgh, London. $12^{\text {th }}$ ed., $518 \mathrm{pp}$.

Manly, B. F. J. (1990): Stage-Structured Populations: Sampling Analysis and Simulation. Chapman and Hall, London and New York .

Serag El-Dien, A. M. (1998): Ecological and biological studies on the Chrysomphalus dictyospermi and Coccus hesperidium. M.Sc. Thesis, Fac. Sci., Cairo Univ., $212 \mathrm{pp}$.

Shalaby, M.S.I. (2002): Ecological and biological studies o the sugarcane scale, Pulvinaria tenuivalvata (Newstead) infesting sugarcane in Giza governorate. Ph. D. Thesis, Fac. Agric., Al-Azhar Univ., 208 pp.

Tohamy, H. T.; Murad, S. A.; Mowafi, K.A. and Twfik, S.F. (2002): Ecological studies on the soft scale insect, Pulvinaria tenuivalvata (Newstead) on sugarcane fields in Minia region, Middle Egypt. $2^{\text {nd }}$ Int. Conf., Plant Protect. Res. Inst., Cairo, Egypt, 21-24 December, (1): 406-414.

\section{ARABIC SUMMARY}

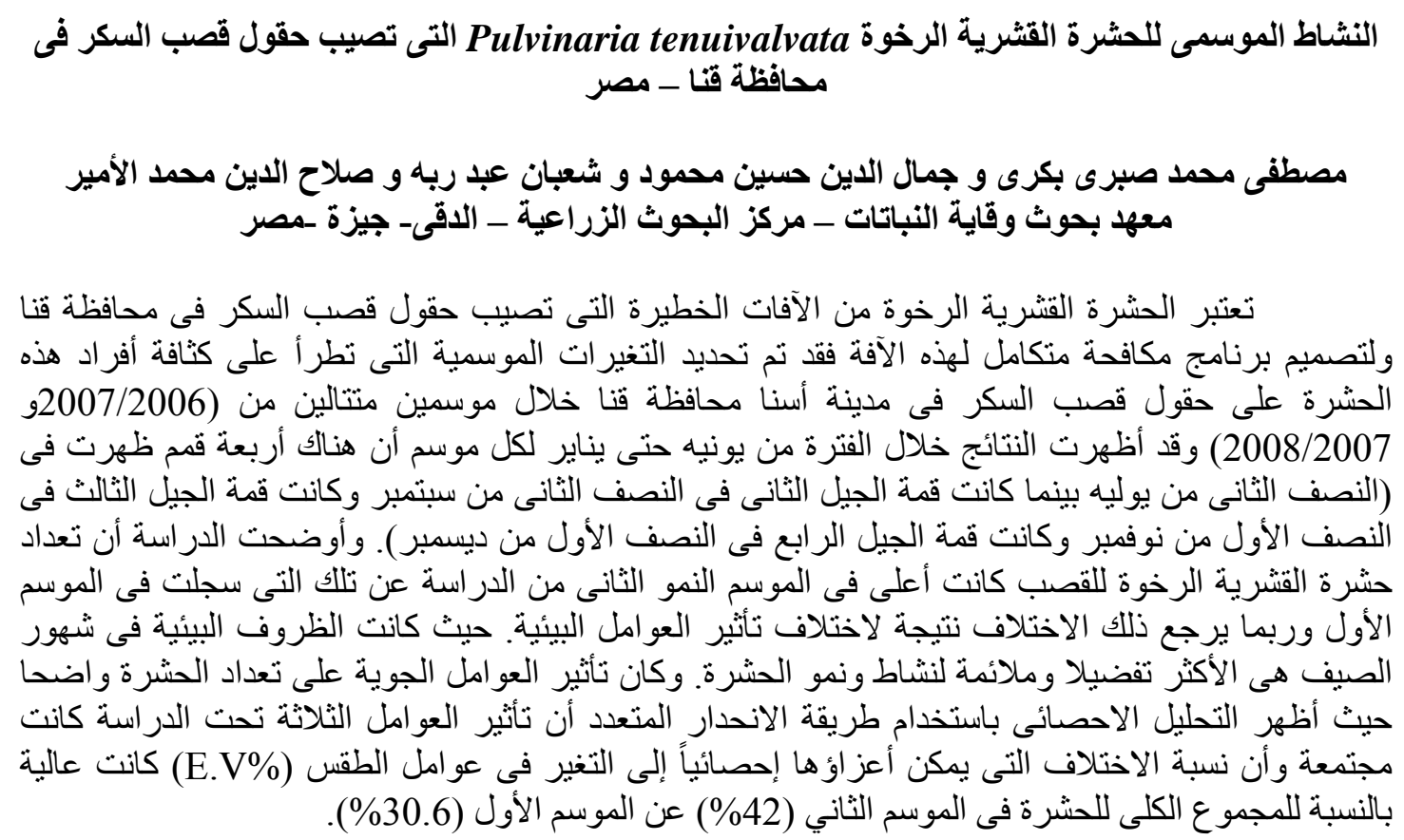

